\title{
Simulating Corporate Income Tax Reform Proposals with a Dynamic CGE Model
}

\author{
Keshab Bhattarai ${ }^{1}$, Jonathan Haughton ${ }^{2}$, Michael Head ${ }^{3} \&$ David G Tuerck ${ }^{2}$ \\ ${ }^{1}$ The Business School, University of Hull, Hull, UK \\ ${ }^{2}$ Department of Economics, Suffolk University, Boston MA, USA \\ ${ }^{3}$ Senior Research Analyst, IBM Watson Health, Cambridge MA, USA \\ Correspondence: Keshab Bhattarai, The Business School, University of Hull, Cottingham Road, Hull, HU6 7SH, \\ UK. Tel: 44-148-246-3207. E-mail: K.R.Bhattarai@hull.ac.uk
}

Received: February 28, 2017

Accepted: March 15, 2017

Online Published: April 5, 2017

doi:10.5539/ijef.v9n5p20

URL: https://doi.org/10.5539/ijef.v9n5p20

\begin{abstract}
Opinion leaders and policy makers in the United States have turned their focus to the corporate income tax, which now has the highest statutory rate in the developed world. Using a dynamic computable general equilibrium model (the "NCPA-DCGE Model"), we simulate alternative policies for reducing the U.S. corporate income tax. We find that reductions in the corporate income tax rate result in significant positive impacts on output, investment, capital formation, employment, and household well-being (for almost all deciles). All of the hypothesized reforms also result in a more-streamlined public sector. These results are plausible insofar as the DCGE model from which they are obtained is parameterized by plausible elasticity assumptions, and incorporates the adjustments in prices, output, employment and investment that result from changes in tax policy.
\end{abstract}

Keywords: corporate income tax, dynamic CGE model, US economy, growth and redistribution

\section{Introduction}

Corporate tax reform re-emerged as a dominant political issue during the 2016 presidential election in the United States. Tax reform proposals had been made earlier by President Barack Obama, and other proposals were put forward by the main presidential candidates, including Donald Trump and Hillary Clinton; some of these are reviewed in Angelini and Tuerck (2015). With the election of Donald Trump, it is an opportune moment to revisit the rich academic literature on the economic effects of corporate taxes, and notably the burden that they place on investment. This paper aims to provide information useful to both the political debate and the academic literature.

The debate over corporate taxes ties into the broader debate over how best to satisfy the two major goals of sound tax policy: efficiency and equity. The tension between the two objectives is inseparable from policy debates, but there is a growing agreement that the existing US tax system is highly inefficient. Mirrlees et al. (2010), writing about the United Kingdom, speak of a hopeful consensus among most economists, observing that "there are taxes that are fairer, less damaging, and simpler than those that we have now. To implement them will take a government ... willing to put long-term strategy ahead of short-term tactics." As early as 1985, Hall and Rabushka (1985) in the U.S. expressed the urgency for tax reform: "it is time for another Declaration of Independence, this time from an unfair, costly, complicated federal income tax. The alternative is a low simple flat tax."

The purpose of this paper is to assess the effects of corporate tax reform on the US economy. This analysis is the first based on the model we have built: the National Center for Policy Analysis - Dynamic Computable General Equilibrium (NCPA-DCGE) model. The purpose of the NCPA-DCGE model is to examine U.S. tax policy changes for their effects on major economic indicators, including:

- The level and distribution of household income;

- GDP, capital investment, and private sector employment;

- Government tax revenues, employment and spending; and,

- Short-term and long-term consumer welfare. 
Dynamic CGE models are the most appropriate tools for assessing the impacts of taxes. For instance, a recent study found significant benefits from the implementation of the FairTax - a sales tax coupled with a rebate designed to de-tax low-income households - in terms of growth and redistribution in the U.S. economy (Bhattarai, Haughton, \& Tuerck, 2015b). This paper focuses on the impacts of changes in corporate income taxes, and the model uses micro-consistent data from a Social Accounting Matrix (SAM2015) for benchmarking.

There are three main reasons why we focus on corporate tax reform here. First, as shown in Figure 1, the United States has the highest statutory tax rate among OECD countries. In their survey of the literature, Angelini and Tuerck (2015) find U.S. corporate rates to be relatively high and to impose a substantial burden on the U.S. economy. While several other countries, including Japan, Germany and the UK, have reduced corporate taxes substantially in recent years, the United States still has a combined federal, state and local corporate tax rate of greater than 39 percent. Overesch and Rincke (2011) provide an analysis of the declining rate of corporate taxes across the OECD economies. Leibrecht and Hochgatterer (2012) and Zellner and Ngoie (2015), attribute these falling rates of corporate taxes in OECD countries to the pace of globalization, and the resulting tax competition.

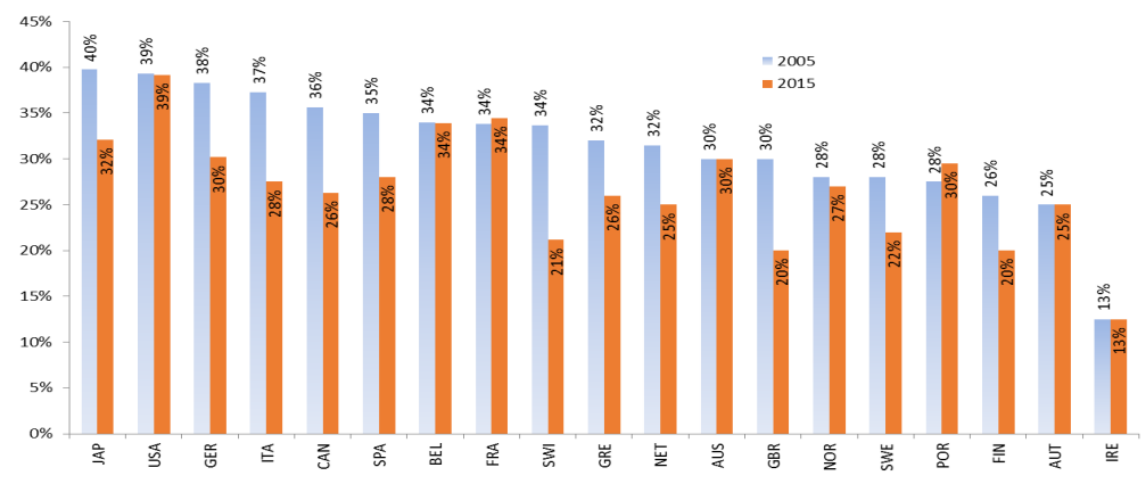

Figure 1. Statutory corporate income tax rates in selected OECD countries, 2005-2015

Data Source. OECD, Tax Database. http://www.oecd.org/tax/tax-policy/tax-database.htm

Second, the high U.S. corporate tax rate appears to represent an inefficient source of revenue. Despite an average tax rate (ATR) for the U.S. corporate income tax that is below the OECD average, the marginal tax rate is high, which creates distortions. As shown in Figure 2, U.S. corporate tax revenue has represented only two percent of GDP in recent years, and is small in comparison to the average of the OECD economies. The U.S. corporate tax contributes about 10 percent of total federal tax revenue, compared to 8.5 percent across OECD countries (Figure 3 ), even though the U.S. has a low tax overall burden relative to other OECD countries (Figure 4). Finally, and as we show below, the existing corporate tax rate imposes a substantial burden on the U.S. economy.

Third, tax reform is back on the political agenda, and is likely to feature prominently in legislative proposals made in 2017 and beyond.

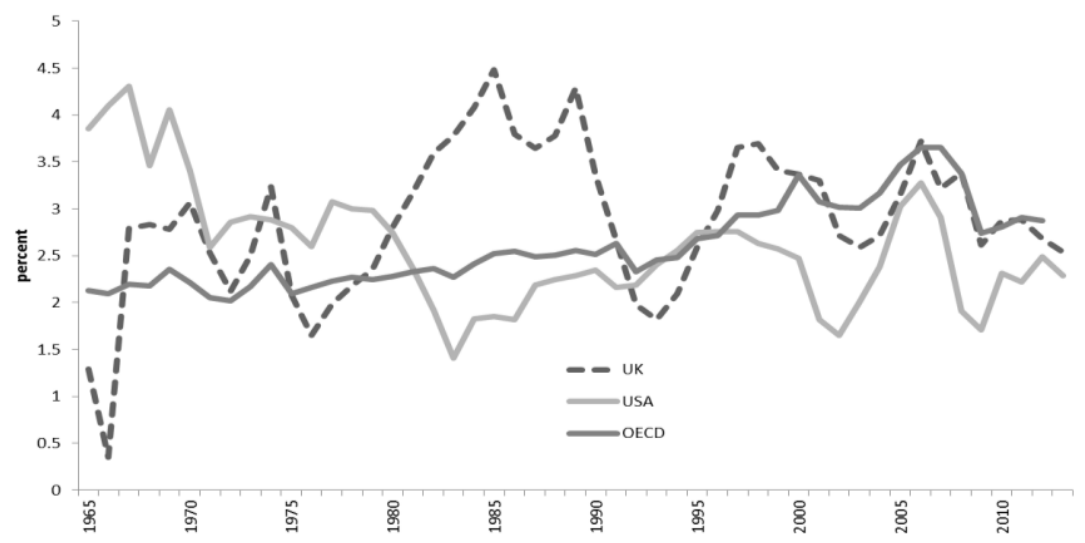

Figure 2. Ratio of corporate tax revenue to GDP for U.S., U.K., and OECD, 1965-2013

Data Source. OECD, Tax Database. http://www.oecd.org/tax/tax-policy/tax-database.htm 


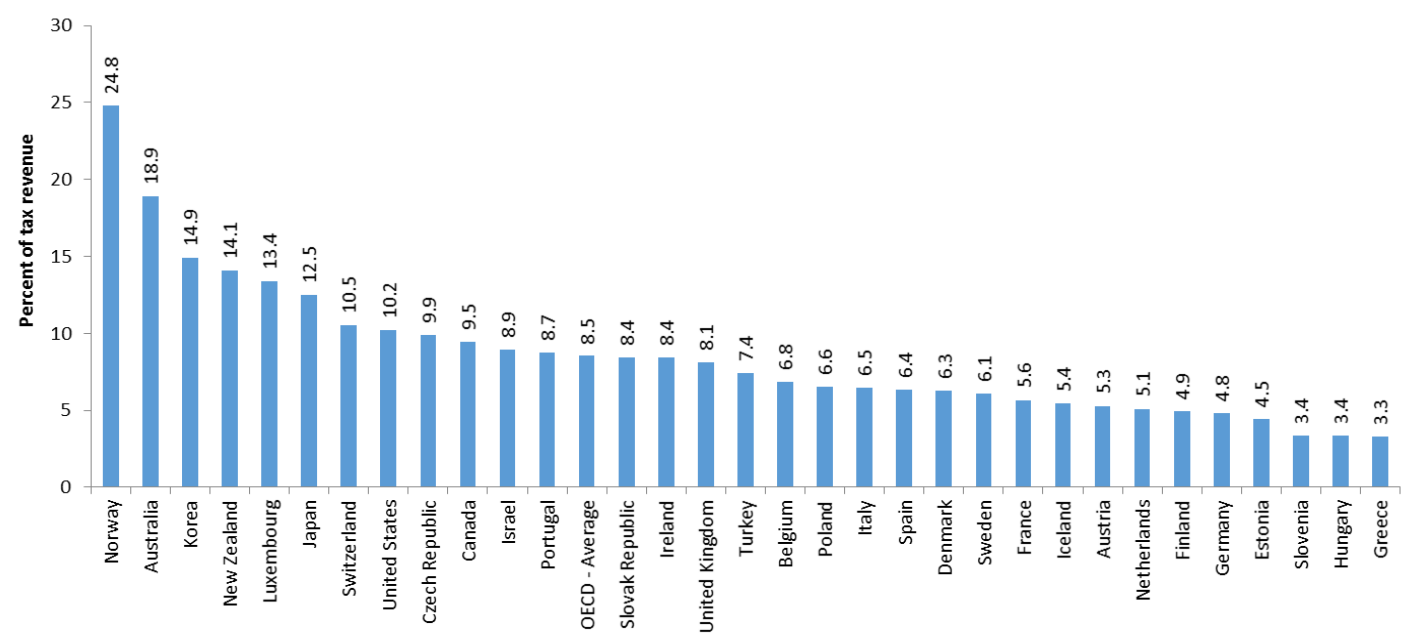

Figure 3. Tax on corporate profits as percentage of tax revenue, 2012

Data Source. OECD, Tax Database. https://data.oecd.org/tax/tax-on-corporate-profits.htm\#indicator-chart

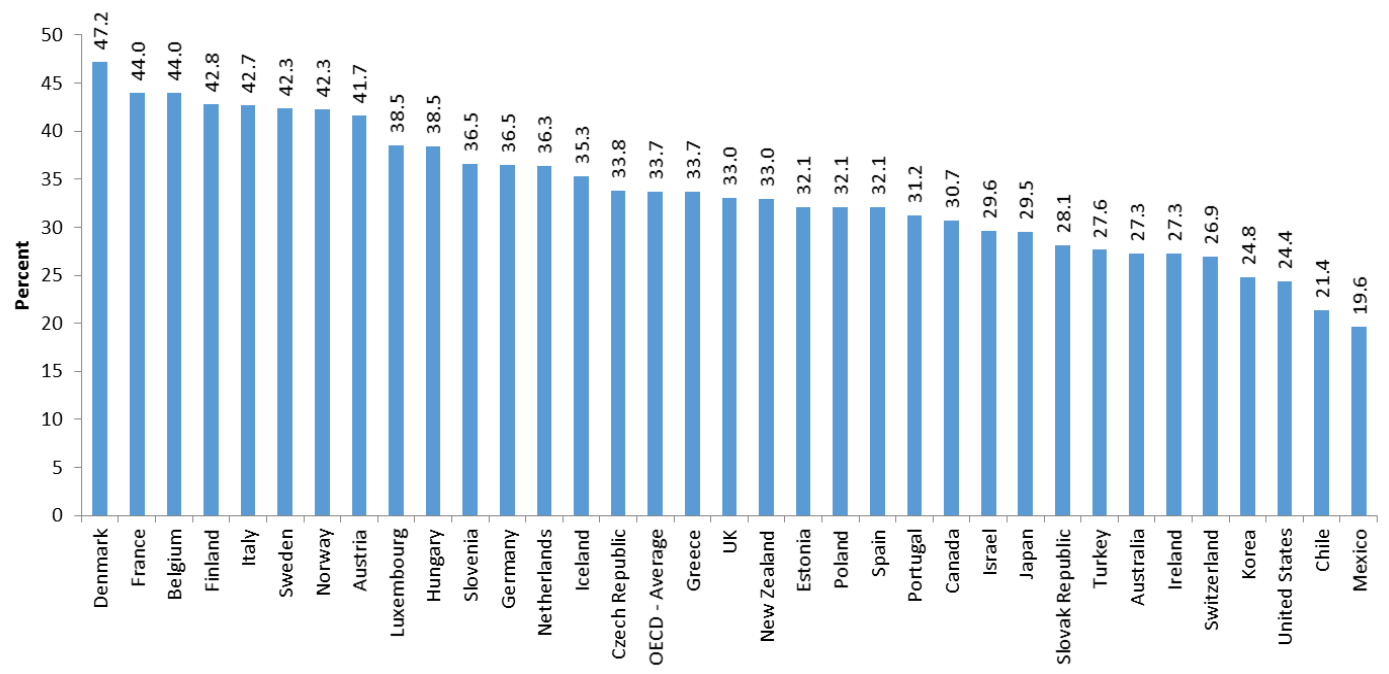

Figure 4. Tax Revenue to GDP Ratios in OECD Countries, 2012

Data Source. OECD, Tax Database. http://www.oecd.org/tax/tax-policy/tax-database.htm

\section{The Formal Specification of the DCGE Model of the U.S. Economy}

There is an extensive literature that identifies the excess burden of corporate taxes on investment. Angelini and Tuerck (2015) show how corporate taxation in the U.S. imposes a double tax on investors. But past studies are mostly comparative static, partial equilibrium analyses.

\subsection{Main Features of the Model}

A general equilibrium model is a complete specification of the price system in which quantities and prices are determined by the interaction of the demand and supply in goods and factor markets. Governments influence market outcomes by altering prices by means of taxes and transfers and, in the process, exert significant impacts on investments and the economic growth rate of various sectors of the economy. The NCPA-DCGE model allows for labor-leisure choices, and consumption-saving choices, both in the current period and over time. The household is assumed to adopt an optimization rule, which it revises in response to tax-policy changes.

In the NCPA-DCGE model, the structural features of the U.S. economy are akin to those adopted in Bhattarai, Haughton and Tuerck (2015a). The model can be used to compare alternative tax policies to determine which are more efficient in terms of maximizing the welfare of U.S. households, consistent with existing levels of 
technology, and labor and capital endowments.

Households and producers optimize, given their budget and time constraints. Price adjustments bring about the most efficient economic outcomes. The general equilibrium is achieved when excess demand is zero in each market for each period, representing balance between demand and supply. The existence of the general equilibrium is guaranteed by fixed point theorems, and the model is solved using the dynamic routines in the GAMS/MPSGE software (Note 1). Given the desirable properties of the Constant Elasticity of Substitution (CES) or Cobb-Douglas demand and supply functions, equilibrium is stable and unique, and will determine the evolution of the model economies from 2017 to 2050. The next sections describe the components of the model in more detail.

\subsection{Preferences}

Infinitely-lived households maximize the present value of utility, as shown in equation (1), which derives from the consumption of goods and services $\left(C_{t}^{h}\right)$ and leisure $\left(L_{t}^{h}\right)$, shown in equation (2). Labor supply, measured as time devoted to work $\left(L S_{t}^{h}\right)$, equals the time endowment minus leisure for each household $h$, as shown by the identity in equation (3).

The welfare and utility of households in this model are nested in three different levels. A composite consumption good for each household is produced from 27 domestic commodities $\left(C_{1}, C_{2}, \ldots C_{27}\right)$ and imports $\left(C_{1 m}, C_{2 m}, \ldots\right.$ $\mathrm{C}_{27 \mathrm{~m}}$ ) at the bottom of the nest (see Figure 5). The second nest shows how households receive utility $U_{t}^{h}$ from consuming goods and services, $C_{t}^{h}$, and leisure, $L_{t}^{h}$, where one can evaluate the trade-off between labor, leisure and consumption simultaneously. A hard-working household will have more labor income to spend on consumption but will be left with less leisure. The ultimate aim of a household is to optimize its lifetime utility, $L U^{h}$, from choices made over the periods in the model. All U.S. households are categorized in one of the ten deciles and indexed by $h=1,2, \ldots 10$, ranked from the lowest to the highest income levels.

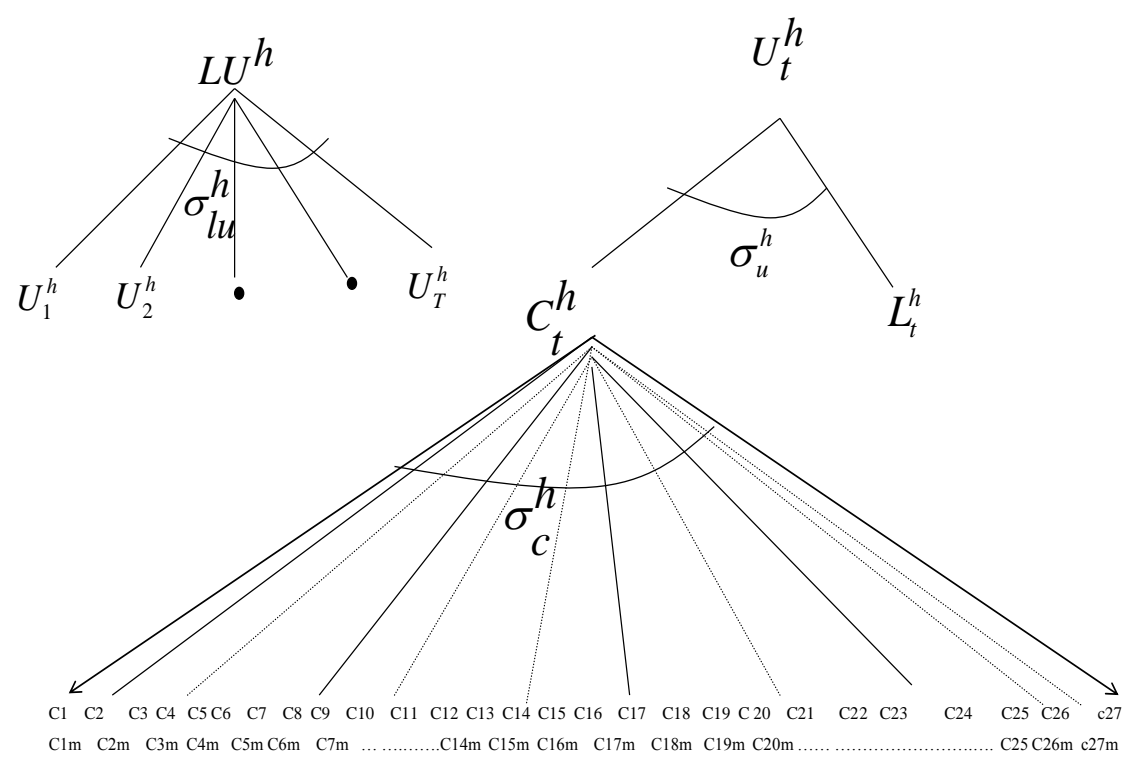

Figure 5. Nesting of Utilities: Lifetime (LU) and Instantaneous (U) utility functions of a household

In the model, infinitely-lived households allocate lifetime income to maximize lifetime utility, which is defined as:

$$
L U^{h}=\sum_{t=0}^{\infty} \beta^{t} \frac{U_{t}^{h, 1-\sigma_{l u}}-1}{1-\sigma_{l u}}
$$

where $\beta$ is the discount factor and depends on the rate of time preference, $L U^{h}$ is the lifetime utility of the household $h, \sigma_{l u}^{h}$ measures the elasticity of intertemporal substitution for household $h$, and $U_{t}^{h}$ is its instantaneous utility function: 


$$
\begin{gathered}
\left.U\left(C_{t}^{h}, L_{t}^{h}\right)=\left(\alpha_{c}^{h} C_{t}^{\frac{\sigma_{u}^{h}-1}{\sigma_{u}^{h}}}+\left(1-\alpha_{c}^{h}\right) L_{t}^{h}\right)^{\frac{\sigma_{u}^{h}-1}{\sigma^{h}}}\right)^{\frac{\sigma_{u}^{h}}{\sigma_{u}^{h}-1}} \\
L S_{t}^{h}=\bar{L}_{t}^{h}-L_{t}^{h} .
\end{gathered}
$$

Here $C_{t}^{h}$ is composite consumption in period $t$, and $L_{t}^{h}$ is leisure in period $t, \alpha_{c}^{h}$ is the consumption share of household $h$, and $\sigma_{c}^{h}$ and $\sigma_{u}^{h}$ respectively represent elasticities of substitution between goods and services and between consumption and leisure. The larger the value of $\sigma_{u}^{h}$, the more responsive are consumption and labor supply to changes in commodity prices and wage rates.

The representative household in each income decile faces an intertemporal budget constraint whereby the present value of its consumption and leisure in all periods cannot exceed the present value of infinite lifetime full income (wealth constraint), $W^{h}$. In the existing tax system, households pay commodity taxes (such as sales taxes or VAT) and labor income tax, and receive transfer income on a means-tested basis. Thus,

$$
\sum_{t=0}^{\infty} \mu(t)\left(P_{t}\left(1+t^{v c}\right) C_{t}^{h}+w_{t}^{h}\left(1-t_{l}\right) L_{t}^{h}\right)=W^{h}
$$

where, $\mu(t)=\prod_{s=0}^{t-1} 1 /\left(1+r_{s}\right)$ is a discount factor, $r_{s}$ represents the real interest rate on assets at time $s, P_{t}$ is the price of composite consumption (which is based on goods prices), $w_{t}^{h}$ is the wage rate for household $h, t^{V C}$ is the sales (or value added) tax on consumption, $t_{l}$ is the labor income tax rate, $C_{t}^{h}$ is composite consumption, which is composed of sectoral consumption goods, and $W^{h}$ is the lifetime wealth of the household. Sectoral aggregations are of the Cobb-Douglas (Note 2) type, so $P_{t}=\theta \prod_{i=1}^{n} p_{i, t}^{\alpha_{i}}$, and $C_{t}=\prod_{i=1}^{n} C_{i, t}^{\alpha_{i}^{h}}$, where $\alpha_{i}^{h}$ gives the share of spending on good $i$ by the representative household. In this case $C_{i, t}^{k}$ is a composite of domestic and foreign sector $j$ products that enter in the consumption basket of the household $h, p_{i, t}$ the gross-of-tax price, and $\theta$ is a constant price index in the base year.

Lifetime income in this model includes the value the household's labor endowment and other income under the benchmark economy. Lifetime wealth $W^{h}$ is defined as:

$$
W^{h}=\frac{J_{0}^{h}}{1+r_{0}}+\frac{J_{1}^{h}}{\left(1+r_{0}\right)\left(1+r_{1}\right)}+\ldots .+\frac{J_{2}^{h}}{\Pi_{s}^{t}\left(1+r_{s}\right)}+\ldots=\sum_{t=0}^{\infty} \mu(t) J_{t}^{h}
$$

where $J_{h}^{t}$ is the household's full disposable income in period $t$, which includes the value of labor endowments and capital income plus transfers. It can be stated as:

$$
J_{t}^{h}=\left(1-t_{l}^{h}\right) w_{t}^{h} \bar{L}_{t}^{h}+\left(1-t_{i, k}\right) r_{i, t} K_{i, t}^{h}+T R_{t}^{h}
$$

where $w_{t}^{h}$ is the wage rate for household $h, L_{i, t}^{n}$ is its labor endowment, $r_{i, t}$ is the rental rate of capital, $K_{i, t}^{n}$ is the capital stock of type $i$ owned by household $h, T R_{t}^{h}$ is the transfer from the federal or the local government to the household $h, t_{l}^{h}$ is the tax rate in labor income paid by household $h$, and $t_{i, k}$ is the corporate tax rate in the use of capital inputs.

We combine equations (1) to (6) to form the Lagrangian for the consumer's intertemporal allocation problem in (7):

$$
\mathfrak{I}^{h}=\sum_{t=0}^{\infty}\left(\frac{1}{1+\rho}\right)^{t} \frac{\left(\left(\alpha_{c}^{h} C_{t}^{\frac{\sigma_{u}^{h}-1}{\sigma_{i}^{h}}}+\left(1-\alpha_{c}^{h}\right) L_{t}^{\frac{\sigma_{u}^{h},-1}{\sigma_{h}^{h}}}\right)^{\frac{\sigma_{u}^{h}}{\sigma_{u}^{h}-1}}\right)^{1-\sigma_{u}^{h}}-1}{1-\sigma_{u}^{h}}+\lambda^{h}\left[\sum_{t=0}^{\infty} \mu(t)\left(P_{t}\left(1+t^{v c}\right) C_{{ }_{t}}^{h}+w_{t}^{h}\left(1-t_{l}\right) L_{t}^{h}+r k_{t}^{h}\left(1-t_{k}\right) K_{t}^{h}\right)-W^{h}\right]
$$


Here, $\sigma_{u}^{h}$ is the intratemporal elasticity of substitution between consumption and leisure, $\sigma_{c}^{h}$ is the consumption share of household $h, \lambda^{h}$ is the shadow price of income in terms of the present value of utility, and $\beta$ is replaced by $1 /(1+\rho)$, where $\rho>0$ is the rate of time preference, which indicates the degree to which the household prefers leisure and consumption in earlier rather than in later years.

\subsection{Production Function}

In each period, the supply process in this economy can be explained by nested production functions for each of the 27 sectors. Producers use intermediate inputs in fixed proportions (a "Leontief" technology), but there is flexibility in the use of capital and labor. The nested production structure in Figure 6 includes a composite labor supply function from ten categories of households; a sector-specific capital accumulation and capital allocation function; a value-added function; a Leontief function between value added and intermediate inputs; a constant elasticity of transformation (CET) export function between U.S. markets and the rest of the world; a constant elasticity of substitution (CES) function between domestically supplied goods and imports; and a measure of total absorption in the economy.

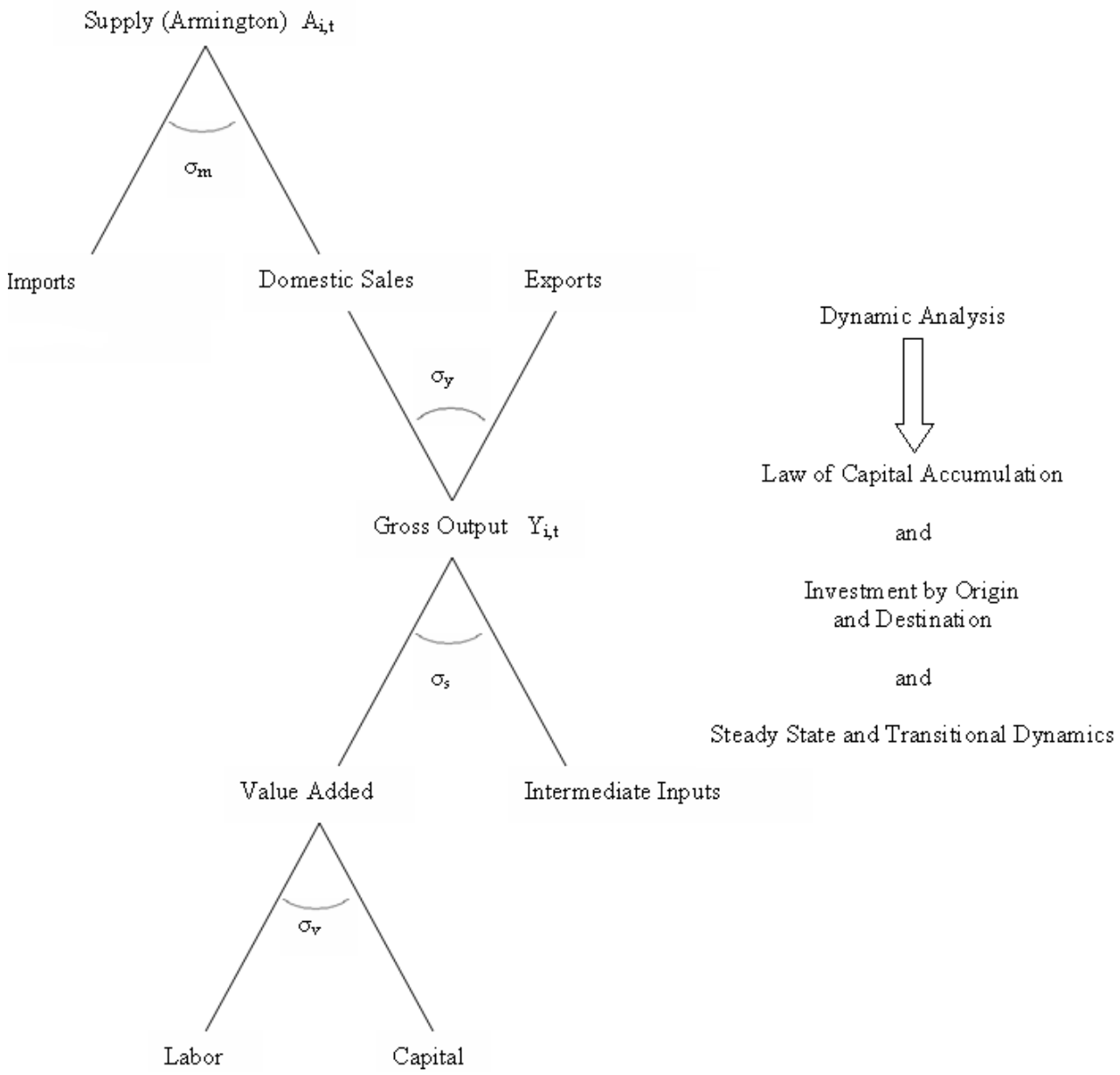

Figure 6. Nested structure of production and trade in the tax model for sector $i$

The objective of a firm in the jth sector of the economy is to maximise the present value of profits subject to production technology constraints. Sectoral profits are given by the differences between the revenue from sales and the cost of supply. The unit revenue function is a Constant Elasticity Transformation (CET) composite of the unit price of domestic sales and the unit price of exports. The unit costs are divided between value-added (i.e. payments to labor and capital), and domestic and imported intermediate inputs in the benchmark economy, given by

$$
\Pi_{j, t}^{y}=\left[\left(\left(1-\delta_{j}^{e}\right) P D_{j, t}^{\frac{\sigma_{y}-1}{\sigma_{y}}}+\delta_{j}^{e} P E_{j, t}^{\frac{\sigma_{y}-1}{\sigma_{y}}}\right)\right]^{\frac{1}{\sigma_{y}-1}}-\theta_{j}^{v} P Y_{j, t}^{v}-\theta_{j}^{d} \sum_{i} a_{i, j}^{d} P_{i, t}-\theta_{j}^{m} \sum_{i} a_{i, j}^{m} P M_{j, t}
$$


where $\Pi_{i, t}^{y}$ is the unit profit of activity in sector $j$; $P E_{i, t}$ is the export price of good $j$; $P D_{i, t}$ is the domestic price of good $j ; P Y_{i, t}^{v}$ is the price of value added per unit of output in activity $j ; \sigma_{y}$ is a transformation elasticity parameter; $P M_{j, t}$ import price of intermediate input; $P_{i, t}$ is the price of final goods used as intermediate goods; $\delta_{j}^{e}$ is the share parameter for exports in total production; $\theta_{j}^{v}$ is the share of costs paid to labor and capital; $\theta_{j}^{d}$ is the cost share of domestic intermediate inputs; $\theta_{j}^{m}$ is the cost share of imported intermediate inputs; the $a_{i, j}^{d}$ are input-output coefficients for domestic supply of intermediate goods; and the $a_{i, j}^{m}$ are input-output coefficients for imported supply of intermediate goods.

Producers maximize the net of tax profit $\left(\Pi F_{i, t}^{y}\right)$ as:

$$
\Pi F_{j, t}^{y}=\left(1-t_{i}\right)\left\{\left[\left(\left(1-\delta_{j}^{e}\right) P D_{j, t}^{\frac{\sigma_{y}-1}{\sigma_{y}}}+\delta_{j}^{e} P E_{j, t}^{\frac{\sigma_{y}-1}{\sigma_{y}}}\right)\right]^{\frac{1}{\sigma_{y}-1}}-\theta_{j}^{v} P Y_{j, t}^{v}-\theta_{j}^{d} \sum_{i} a_{i, j}^{d} P_{i, t}-\theta_{j}^{m} \sum_{i} a_{i, j}^{m} P M_{j, t}\right\}
$$

The government takes a part of pre-tax profit as its revenue from taxes on profits $\left(R_{F}\right)$ as:

$$
R_{F}=t_{i} \Pi_{j, t}^{y}=t_{i}\left\{\left[\left(\left(1-\delta_{j}^{e}\right) P D_{j, t}^{\frac{\sigma_{y}-1}{\sigma_{y}}}+\delta_{j}^{e} P E_{j, t}^{\frac{\sigma_{y}-1}{\sigma_{y}}}\right)\right]^{\frac{1}{\sigma_{y}-1}}-\theta_{j}^{v} P Y_{j, t}^{v}-\theta_{j}^{d} \sum_{i} a_{i, j}^{d} P_{i, t}-\theta_{j}^{m} \sum_{i} a_{i, j}^{m} P M_{j, t}\right\}
$$

At the bottom of the nest of the production side of the economy, producers use labor and capital in each of $N$ sectors to produce value added. The amount of each type of these inputs employed by a producer in a particular sector is based upon the sector-specific production technology and input prices. We use a CES function to express this relationship:

$$
Y_{i, t}=\Omega_{i}\left(\left(1-\delta_{i}\right)\left(K_{i, t}\right)^{\sigma_{v}}+\delta_{i}\left(L S_{i, t}\right)^{\sigma_{v}}\right)^{\frac{1}{\sigma_{v}}}
$$

where $Y_{i, t}$ is the gross value added of sector i, $\Omega_{i}$ is a shift or scale parameter in the production function, $K_{i, t}$ and $L S_{i, t}$ are the amounts of capital and labor used in sector $i, \delta_{i}$ is the share parameter of labor in production, and $\sigma_{v}$ is the CES substitution elasticity parameter. This is a constant-returns-to-scale production function. Euler's product exhaustion theorem implies that total output (value added) equals payments to labor and capital, and each factor receives remuneration at the rate of its marginal productivity:

$$
P Y_{i, t} Y_{i, t}=w_{t} L S_{i, t}+r k_{i, t} K_{i, t}
$$

where $w_{t}$ is the gross-of-tax composite wage rate that the employer pays to use labor input, and $r k_{i, t}$ is the gross rental rate of capital. Note that $w_{t}$ is a composite of wage rates for each category of household, $w_{t}^{h}$; similarly, $L S_{i, t}$ is the composite of $L S_{i, t}^{n}$, the labor supplied by households, for $h=1,2, \ldots, 10$.

Then the second nest in production is given by the relationship between the intermediate inputs and gross output as expressed by input-output coefficients, which form a fixed physical non-price based constraint on the production system. The general form of the production function is:

$$
G Y_{i, t}=\min \left(Y_{i, t},\left(\frac{D I_{i, j, t}}{a_{i, j}^{d}}\right)_{i=j},\left(\frac{M I_{i, j, t}}{a_{i, j}^{m}}\right)_{i=j}\right)
$$

where the $a_{i, j}^{d}$ are input-output coefficients for domestic supply of intermediate goods; $a_{i, j}^{m}$ are input-output coefficients for imported supply of intermediate goods, $D I_{i, j, t}$ is the supply of domestic intermediate input and $M I_{i, j, t}$ is the supply of imported intermediate inputs. The presence of input-output linkages in the model enables us to assess various kinds of backward and forward impacts of policy changes. For instance, a tax on agricultural output has a direct effect on demands for agricultural goods, and a backward impact that spreads to other sectors that provide inputs to that sector. Similarly, through forward linkages, the tax affects the cost of agricultural inputs to other sectors. For this NCPA-DCGE model these domestic input-output coefficients are obtained from the 27 sector input-output table contained in the Social Accounting Matrix.

\subsection{Labor Supply and Capital Accumulation}

The underlying growth rate in the DCGE model is determined by the growth rate of labor and capital. The labor supply, $L S_{t}^{h}$ for each household $h$ is given by the difference between the household labor endowment, $\bar{L}_{t}^{h}$, and the demand for leisure, $L_{t}^{h}$. 


$$
L S_{t}^{h}=\bar{L}_{t}^{h}-L_{t}^{h}
$$

In equilibrium, the wage rate must be such that the labor supplied by the household equals the total demand for labor derived from the profit maximizing behavior of firms (as set out above).

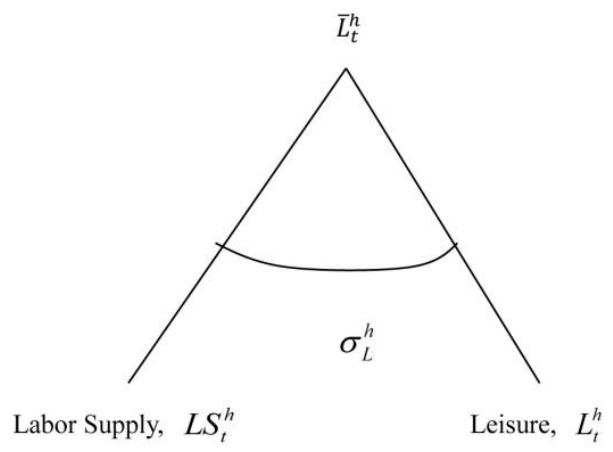

Figure 7. Time endowment of household

Capital accumulation in sector $i$ in period $t+1$ is then given by the capital stock of period $t$ net of depreciation and investment:

$$
K_{i, t+1}=K_{i, t}\left(1-\delta_{i}\right)+I_{i, t}
$$

where $K_{i, t+1}$ is the capital stock in sector $i$ for period $t+1, \delta_{i}$ is the sector-specific rate of depreciation, and $I_{i, t}$ is the net investment for sector $i$ in period $t$.

Growth in sectoral output depends both upon the growth of employment and the growth of the capital stock in that sector. On a balanced-growth path, where all prices are constant and all real economic variables grow at a constant rate, capital stocks must grow at a rate fast enough to sustain growth. This condition can be expressed as:

$$
I_{i, T}=K_{i, T}\left(g_{i}+\delta_{i}\right)
$$

where the subscript $T$ denotes the terminal period of the model, and $g_{i}$ is the growth rate for sector $i$ in the steady state and is assumed uniform across sectors for the benchmark economy.

Although the time horizon of households and firms is infinite, in practice the model must be computed for a finite number of years. Our model is calibrated using data for 2017 and stretches out for 33 years (i.e. through 2050). To ensure that households do not consume the capital stock prior to the (necessarily arbitrary) end point, a "transversality" condition is needed, characterizing the "steady state" that is assumed to reign after the end of the time period under consideration. We assume, following Ramsey (1928) that the economy returns to the steady state growth rate of 3 percent at the end of the final period $\mathrm{T}$.

The model also requires a number of identities. After-tax income is either consumed or spent on savings (which equals investment here). Net consumption is defined as gross consumption spending less any consumption tax. The flow of savings is defined as the difference between after-tax income and gross spending on consumption, and gross investment equals national saving plus foreign direct investment.

\subsection{Foreign Direct Investment and Capital Inflows}

The zero trade balance is a property of a Walrasian general equilibrium model; export or import prices adjust until the demand equals supply in international markets. However, foreign direct investment (FDI) plays a crucial role in the U.S. economy as exports and imports are not automatically balanced by automatic price adjustments. Therefore the Walrasian model is modified here to incorporate capital inflows so that the FDI can pay for whenever imports exceed exports.

$$
F D I_{t}=\sum_{i} P M_{i, t} M_{i, t}-\sum_{i} P E_{i, t} E_{i, t}
$$

where for period $t, F D I_{t}$ is the amount of net capital inflows into the U.S. economy, $\sum_{i} P M_{i, t} M_{i, t}$ is the volume of imports and $\sum_{i} P E_{i, t} E_{i, t}$ is the volume of exports. 
This DCGE model assumes that the FDI is only used to import investment goods. Larger amounts of FDI increase investment, capital stock, output, utility level and lifetime well-being of households in the model.

\subsection{Calibration}

The model is truly "dynamic" in that it optimizes the lifetime utility of households and profits of firms over time, given their constraints, and is calibrated using SAM data for 2017. The model is programmed in General Algebraic Modeling System (GAMS) along with it Mathematical Programming for System of General Equilibrium (MPSGE) module, a specialized program that is widely used for solving DCGE models (Note 3).

The dynamics in this model arise from an endogenous process of capital accumulation and exogenous growth rate of the labor force. We rule out uncertainty and rely on the perfect foresight of households and firms, which means that actual and expected values of variables are the same.

There are essentially five steps involved in calibration of this dynamic model. The first step relates to forming a relation between the price of commodities at period $t, P_{i, t}$, and the price of investment good PINV $V_{i, t}$. Then the composite investment generates capital stock in period $t+l$ with price $P_{i, t+1}^{k}$. It also needs a link between the prices of the capital stock at periods $t$ and $t+1, P_{i, t}^{k}, P I N V_{i, t}$, and $P_{i, t+1}^{k}$, with due account of the rental on capital and the depreciation rate. For instance, one unit of investment made using one unit of output in period $t$ generates one unit of an investment good. This then generates one unit of capital stock in period $t+1$. This implies that:

$$
P_{i, t} \Rightarrow P I N V_{i, t} \Rightarrow P_{i, t+1}^{k}
$$

Where $P_{i, t}$ is the price of one output in period $t$, and $P I N V_{i, t}$ and $P_{i, t+1}^{k}$ are the $t$ period prices of one unit of investment, and capital goods, in period $t+1$ in sector $i$. Capital depreciates at the rate $\delta_{i}$. One unit of capital at the beginning of period $t$ in sector $i$ earns a rental rate $r k_{i, t}$ at time $t$, and $(1-\delta)_{i}$ units of it remain for the next period (or at the start of the $t+1$ period), $(1-\delta) P_{t+1}^{k}$. Therefore:

$$
P_{i, t}^{k}=r k_{i, t}+(1-\delta) P_{i, t+1}^{k}
$$

The second step involves setting up a link between the rental rate with the benchmark interest rate and the depreciation rate; the rental covers depreciation and interest payments for each unit of investment. If the rental is paid at the end of the period, then:

$$
r k_{i, t}=\left(r+\delta_{i}\right) P_{i, t+1}^{k}
$$

The third step involves forming a relation between the future and the current price of capital, which is just the benchmark reference price as given by:

$$
\frac{P_{i, t+1}^{k}}{P_{i, t}^{k}}=\frac{1}{1+r}
$$

This means that the ratio of prices of the capital at period $t$ and $t+1$ equals the market discount factor $1 /(1+\mathrm{r})$.

The fourth step involves setting up the equilibrium relationship between capital earnings (value added from capital) and the cost of capital. We compute values for sectoral capital stocks from sectoral capital earnings in the base year. If capital income in sector $i$ in the base year is $\bar{V}_{i}$, we can write $\bar{V}_{i}=r k_{i} K_{i}$. Since the return to capital must be sufficient to cover interest and depreciation, we can also write

$$
\overline{V_{i}}=\left(r+\delta_{i}\right) P_{i, t+1}^{k} K_{i}
$$

or

$$
K_{i}=\frac{\bar{V}_{i}}{\left(r+\delta_{i}\right)}
$$

with normalization $P_{t}=P_{t+1}^{k}=1$.

The fifth step involves setting up the relation between the investment and capital earning on the balanced growth path. Investment should be enough to provide for growth and depreciation, $I_{i}=\left(g_{i}+\delta_{i}\right) K_{i}$, which implies that:

$$
I_{i}=\frac{\left(g_{i}+\delta_{i}\right)}{\left(r+\delta_{i}\right)} \overline{V_{i}} .
$$


Thus investment per sector is tied to earnings per sector. In the benchmark equilibrium, all reference quantities grow at the rate of labor force growth, and reference prices are discounted on the basis of the benchmark rate of return. The balance between investment and earnings from capital is restored here by adjustment in the growth rate $g_{i}$, which responds to changes in the marginal productivity of capital associated to change in investment. Readjustment of capital stock and investment continues until this growth rate and the benchmark interest rates become equal.

If the growth rate in sector $i$ is larger than the benchmark interest rate, then more investment will be drawn to that sector. The capital stock in that sector rises as more investment takes place. Eventually, the declining marginal productivity of capital retards growth in that sector. In addition, the DCGE model builds scenarios for open capital markets and capital inflows to evaluate the impacts of corporate tax reforms anticipated in 2017.

To solve the model, we allow for a time horizon sufficient enough to approximate the balanced-growth path for the economy. Currently the model uses a thirty-three year horizon, which can be increased if the model economy does not converge to the steady state.

\section{The Current Tax System and Elasticities}

The effective tax rates currently falling on labor and capital inputs, household income, sales of goods and services, social security, and employment are presented in Table 1. The rates show considerable variation, which convinces us that that the current structure of taxes in the U.S. economy is complex. The current system is neither efficient nor economical, nor good for horizontal or vertical equity among individuals.

Table 1 . Tax rates by sector

\begin{tabular}{|c|c|c|c|c|c|}
\hline & Labor inputs & Capital inputs & Social security tax & Sales, excise, VAT & Deprec-iation rates \\
\hline Agriculture, forestry and fishing & 0.019 & 0.096 & 0.051 & 0.208 & 0.079 \\
\hline Mining & 0.058 & 0.120 & 0.059 & 0.344 & 0.077 \\
\hline Construction & 0.011 & 0.084 & 0.049 & 0.052 & 0.127 \\
\hline Food and tobacco products & 0.126 & 0.174 & 0.059 & 0.055 & 0.079 \\
\hline Textiles and apparel & 0.058 & 0.154 & 0.042 & 0.343 & 0.074 \\
\hline Building materials & 0.021 & 0.091 & 0.051 & 0.128 & 0.091 \\
\hline Paper and publishing & 0.038 & 0.096 & 0.050 & 0.249 & 0.100 \\
\hline Chemicals, petroleum, rubber and plastics & 0.092 & 0.105 & 0.052 & 0.125 & 0.096 \\
\hline Electronics and electronic equipment & 0.029 & 0.033 & 0.042 & 0.018 & 0.111 \\
\hline Motor vehicles and other transportation & 0.064 & 0.125 & 0.063 & 0.150 & 0.155 \\
\hline Other manufacturing & 0.097 & 0.173 & 0.055 & 0.063 & 0.123 \\
\hline Transportation & 0.035 & 0.145 & 0.042 & 0.226 & 0.061 \\
\hline Communications & 0.077 & 0.178 & 0.048 & 0.107 & 0.101 \\
\hline Wholesale trade & 0.074 & 0.157 & 0.064 & 0.092 & 0.118 \\
\hline Retail trade & 0.094 & 0.221 & 0.043 & 0.210 & 0.063 \\
\hline Banking & 0.065 & 0.100 & 0.073 & 0.075 & 0.107 \\
\hline Real estate & 0.005 & 0.097 & 0.052 & 0.039 & 0.027 \\
\hline Personal and repair services & 0.020 & 0.165 & 0.048 & 0.178 & 0.180 \\
\hline Management and administration & 0.066 & 0.158 & 0.045 & 0.064 & 0.112 \\
\hline Health services & 0.007 & 0.243 & 0.056 & 0.080 & 0.067 \\
\hline Entertainment and hotel services & 0.016 & 0.116 & 0.061 & 0.078 & 0.062 \\
\hline Other services & 0.012 & 0.209 & 0.065 & 0.039 & 0.049 \\
\hline Computers & 0.110 & 0.174 & 0.097 & 0.061 & 0.193 \\
\hline Primary and fabricated metal & 0.064 & 0.148 & 0.059 & 0.096 & 0.072 \\
\hline Machinery and instruments & 0.105 & 0.173 & 0.132 & 0.159 & 0.100 \\
\hline Electricity - gas - sanitary & 0.019 & 0.107 & 0.063 & 0.678 & 0.038 \\
\hline Insurance & 0.077 & 0.093 & 0.072 & 0.086 & 0.133 \\
\hline
\end{tabular}

Source: Derived from SAM 2017.

Elasticities of substitution measure the responses of relative changes in quantities to relative changes in prices of goods and services and factors of production in the economy. More flexible markets have larger values of elasticities. A dynamic CGE model is constructed with sets of elasticities in consumption, production, trade and inter-temporal choices of households and firms. For 15 of the sectors we use an elasticity of substitution in production of 0.9 , and employ an elasticity of 0.8 for the remaining 12 sectors (Note 4). The elasticity of 
transformation of imports is set at 1.65, except for wholesaling, retailing, entertainment and hotel services, health services, and other services, where it is pegged at 0.65 . The other key parameters used in the model are shown in Table 2.

Table 2. Key Parameters of the NCPA-DCGE model

\begin{tabular}{lc}
\hline Steady state growth rate for sectors $(g)$ & 0.03 \\
Net interest rate in non-distorted economy $($ or $\varrho$ ) & 0.04 \\
Sector specific depreciation rates $\left(\delta_{\mathrm{i}}\right)$ & $0.02-0.19$ \\
Elasticity of substitution in domestic returns and capital flows, $\sigma_{\mathrm{k}}$ & 1.4 \\
Elasticity of substitution for composite investment, $\sigma$ & 1.3 \\
Elasticity of transformation between U.S. domestic supplies and exports to the Rest of the World (ROW), $\sigma_{\varepsilon}(\mathrm{can}$ be & 2.0 \\
sector-specific) & 1.5 \\
Elasticity of substitution between U.S. domestic products and imports from the Rest of the World (ROW), $\sigma_{\mathrm{m}}$ & 0.98 \\
Inter-temporal elasticity of substitution, $\sigma_{\mathrm{Lu}}$ & 1.5 \\
Intra-temporal elasticity of substitution between leisure and composite goods, $\sigma_{\mathrm{u}}$ & 1.5 \\
Elasticity of substitution in consumption goods across sectors, $\sigma_{\mathrm{C}}$ & 1.2 \\
Elasticity of substitution between capital and labor, $\sigma_{\mathrm{v}}$ & $(1+g)^{t-1}$ \\
Reference quantity index of output, capital and labor for each sector, $Q_{r f}$ & $1 /(1+r)^{t-1}$ \\
Reference index of price of output, capital and labor for each sector, $P_{r f}$ & \\
\hline
\end{tabular}

The NCPA-DCGE model is calibrated to input-output data obtained from the U.S. Bureau of Economic Analysis and projected to 2017 . The model contains 10 household groups organized by income deciles and 27 production sectors. Its horizon spans the period 2017 to 2050. This is a large model with 50,662 variables. Equilibrium is unique and stable for a range of values of these sets of parameters.

\section{Results of the DCGE with Corporate Tax Reforms}

Our analysis begins with a central specification with a fifty percent reduction in the corporate tax rate across all sectors. The corporate tax base is defined as the total revenue of a firm minus the costs of intermediate inputs, wages and imported inputs. At the macro level our analysis focuses on the impacts on real GDP, employment, wages, investment, consumption, exports, and imports. We then consider the micro details of households and firms to determine the impacts of tax reforms on the distribution of income, labor supply and consumption among households, and output, investment, capital accumulation and prices for each of the 27 production sectors.

\subsection{Impacts on Economic Growth}

The macroeconomic impacts of a 50 percent reduction in corporate taxes are very powerful. Real GDP expands relative to the benchmark, initially by 1.6 percent and ultimately by 4.3 percent. This increase in output is made possible by an increase in investment and capital accumulation, and an associated increase in the level of employment in the economy. More saving lowers the growth rate of consumption initially, but consumption rises to 3.5 percent above the counterfactual benchmark (of no cut in the corporate tax rate) by 2042 . The detailed time profile of the macro impacts is shown in Table 3 and in Figure 8. The macro impacts of alternative taxes are presented in Section 5.

Table 3. Summary of effects of 50 percent reduction in corporate income tax rate, 2017-2042

\begin{tabular}{lcccccccccc}
\hline \multicolumn{1}{c}{ Year } & 2017 & 2018 & 2019 & 2020 & 2021 & 2027 & 2032 & 2037 & 2042 \\
\multicolumn{1}{c}{ Period } & 1 & 2 & 3 & 4 & 5 & 10 & 15 & 20 \\
& & \multicolumn{7}{c}{ percentage change relative to baseline of no tax change } \\
Real GDP & 1.6 & 1.7 & 1.9 & 2.2 & 2.4 & 3.4 & 3.8 & 4.1 \\
Investment & 7.2 & 7.1 & 7.2 & 7.4 & 7.4 & 7.7 & 7.8 & 7.9 \\
Capital stock & 0.0 & 0.2 & 0.8 & 1.4 & 1.9 & 4.3 & 5.6 & 6.4 \\
Employment & 2.9 & 3.3 & 3.3 & 3.3 & 3.3 & 3.4 & 3.4 & 3.5 \\
Consumption & 0.0 & 0.3 & 0.6 & 0.9 & 1.3 & 2.6 & 3.1 \\
\hline
\end{tabular}



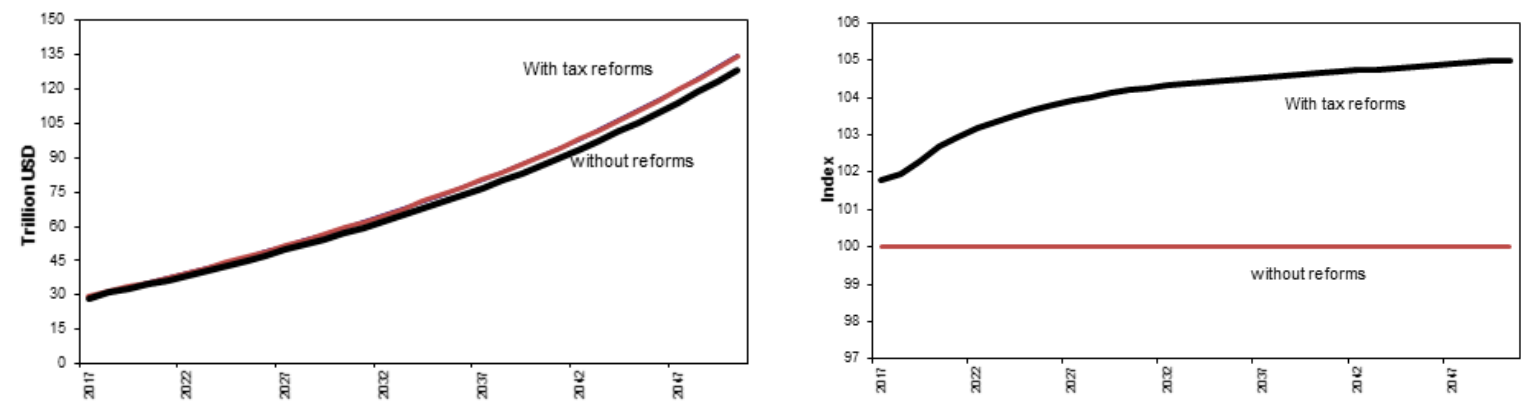

Level of real GDP

Real output
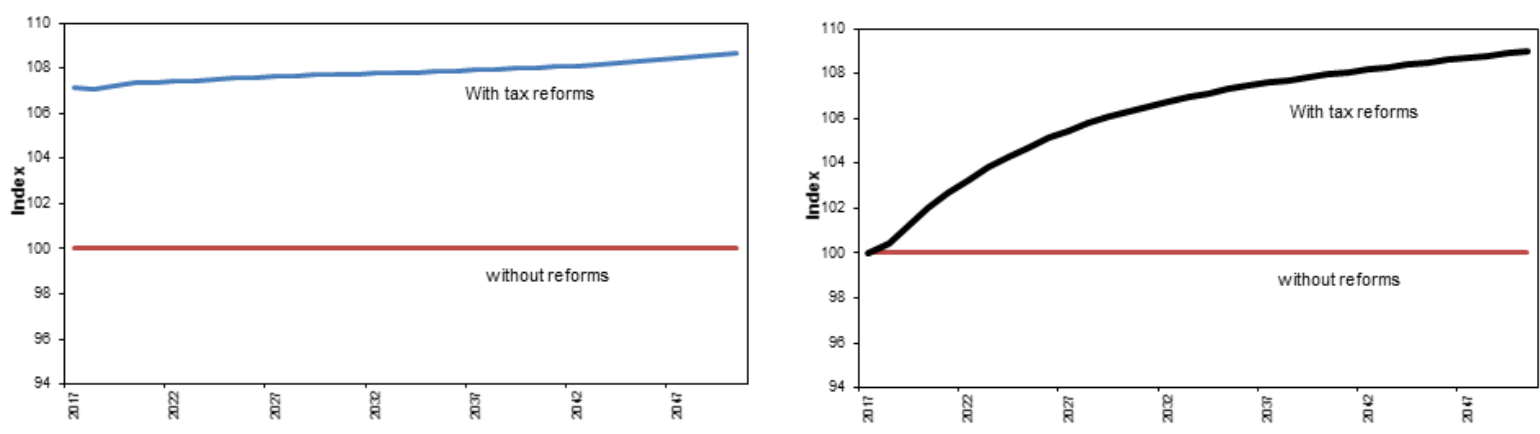

Investment

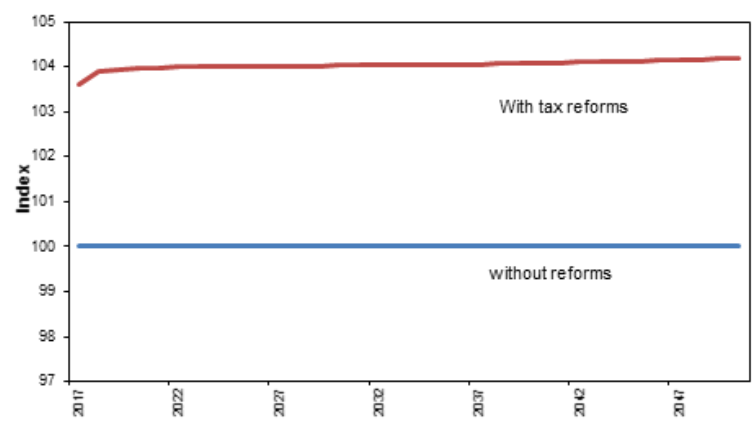

Capital stock

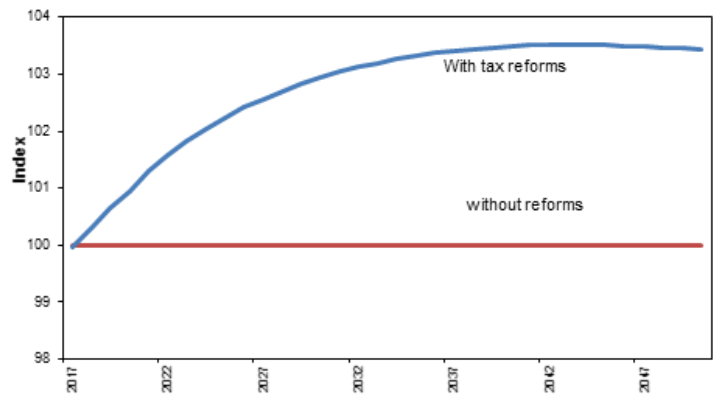

Employment

Consumption

Figure 8. Economic effects of a 50 percent reduction in the corporate income tax rate

Both investment and capital stock keep rising under the tax-change scenario relative to benchmark as shown in the central panels of Figure 8. GDP is above the benchmark economy for most of the years. This is possible because of the increase in capital accumulation that raises the productivity of workers. Similarly, total employment also rises in the beginning relative to the benchmark because the abundantly available capital results in more demand for labor. Total investment also follows the pattern of total output.

\subsection{Impacts on the Distribution of Income}

The income of households rises under the rate reduction, as reported in Table 4 and shown visually in the top panel of Figure 9. Labor supplies of households in all deciles rise relative to the benchmark. This is the result of growth in both in supply and demand for labor following the growth of GDP. Only households in the poorest decile are worse off in terms of wellbeing and consumption, as the reduction in revenue causes a reduction in government transfer payments going to these households. 
Table 4. Distributional effects on household income of 50 percent reduction in corporate income tax

\begin{tabular}{|c|c|c|c|c|c|c|c|c|}
\hline Year & 2017 & 2022 & 2027 & 2032 & 2037 & 2042 & 2047 & 2050 \\
\hline Period & 1 & 5 & 10 & 15 & 20 & 25 & 30 & 33 \\
\hline & \multicolumn{8}{|c|}{ percentage change in income relative to baseline of no tax change } \\
\hline Decile 1 (poor) & 3.13 & 2.12 & 1.62 & 1.35 & 1.23 & 1.25 & 1.38 & 1.51 \\
\hline Decile 2 & 1.70 & 1.23 & 0.85 & 0.66 & 0.59 & 0.62 & 0.76 & 0.89 \\
\hline Decile 3 & 1.30 & 1.02 & 0.69 & 0.52 & 0.47 & 0.52 & 0.66 & 0.80 \\
\hline Decile 4 & 1.68 & 1.29 & 0.93 & 0.74 & 0.68 & 0.72 & 0.87 & 1.00 \\
\hline Decile 5 & 1.18 & 1.02 & 0.71 & 0.55 & 0.51 & 0.57 & 0.72 & 0.86 \\
\hline Decile 6 & 1.16 & 0.99 & 0.68 & 0.52 & 0.48 & 0.54 & 0.69 & 0.83 \\
\hline Decile 7 & 1.12 & 0.97 & 0.67 & 0.51 & 0.47 & 0.53 & 0.69 & 0.83 \\
\hline Decile 8 & 0.87 & 0.82 & 0.55 & 0.40 & 0.37 & 0.44 & 0.60 & 0.74 \\
\hline Decile 9 & 1.21 & 1.01 & 0.70 & 0.53 & 0.49 & 0.54 & 0.69 & 0.83 \\
\hline Decile 10 (rich) & 2.25 & 1.72 & 1.33 & 1.12 & 1.05 & 1.09 & 1.24 & 1.39 \\
\hline
\end{tabular}
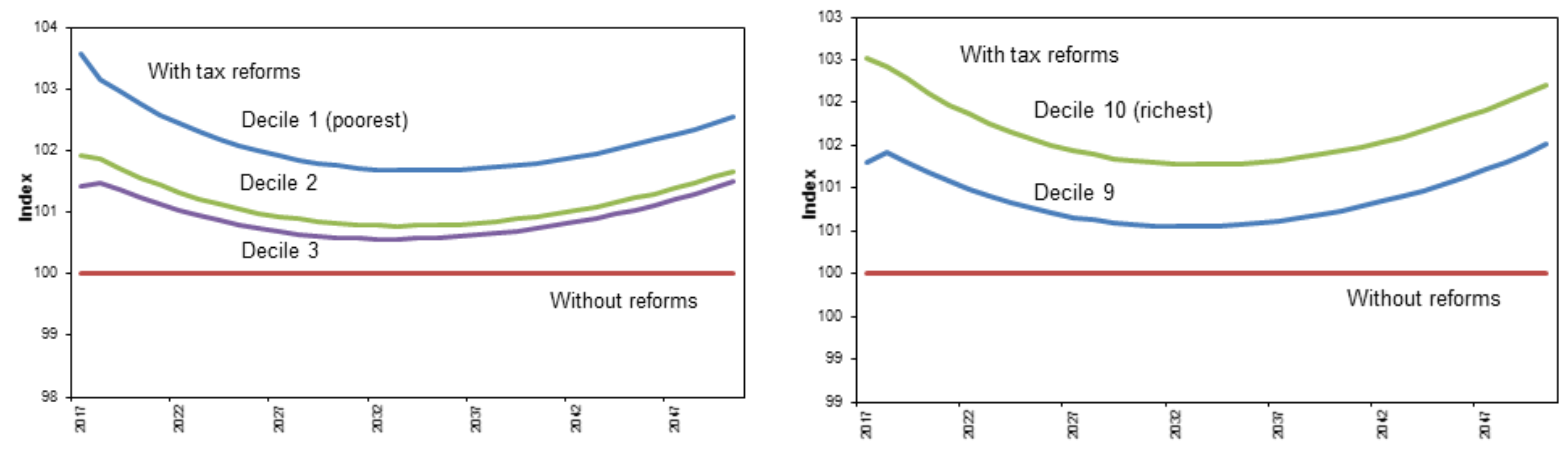

Income
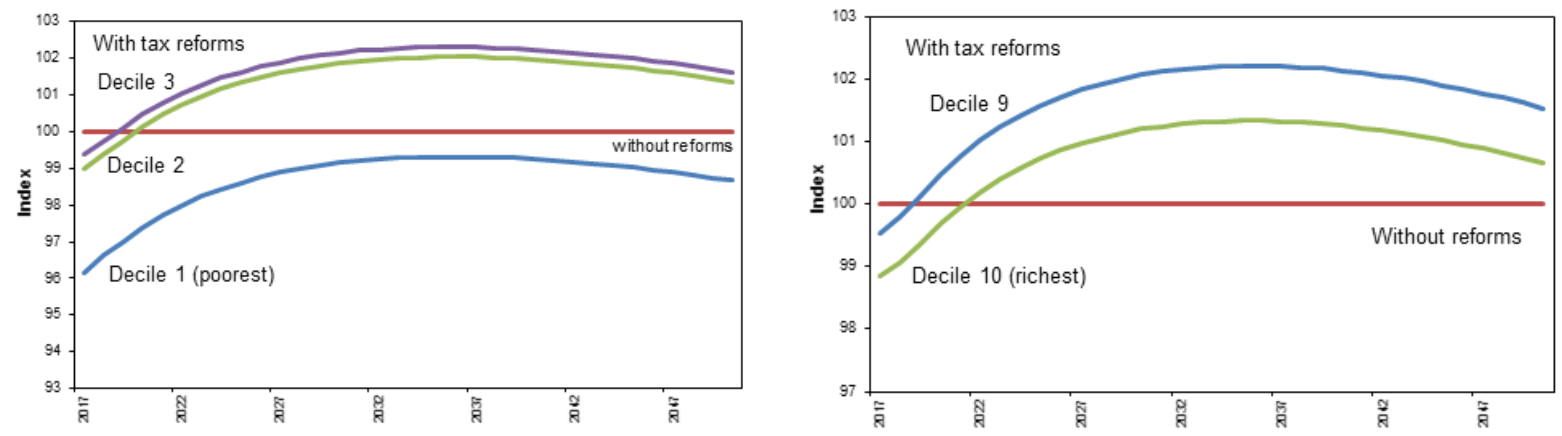

Wellbeing (utility)

Figure 9. Changes in income and wellbeing (utility) under corporate tax reform

Note. Assumes a 50 percent reduction in the corporate tax rate. Income and wellbeing levels in the benchmark case are indexed to 100; the curves show the effects, relative to the benchmark, of the tax change on income (top panels) and wellbeing (bottom panels) for the three poorest and two richest deciles (as measured by income per capita).

\subsection{Revenue and Trade Effects}

Government revenue declines by 11 percent because of the 50 percent reduction in the corporate income tax rate, but it begins to recover modestly in subsequent years as the tax base rises because of the expansion of the economy, as shown in the left-hand panel of Figure 10. The level of exports and imports both expand under the corporate tax reforms, but exports increase faster than imports (see right-hand panel of Figure 10). Thus, the expansionary impacts of corporate tax reforms are helpful in solving the initial imbalances in trade. This is because lower corporate taxes encourage domestic firms to produce at home and attract firms located in other countries to produce in the US. 


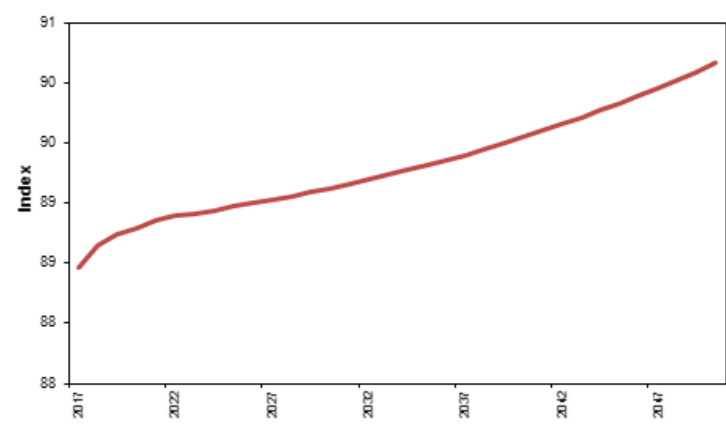

Government revenue

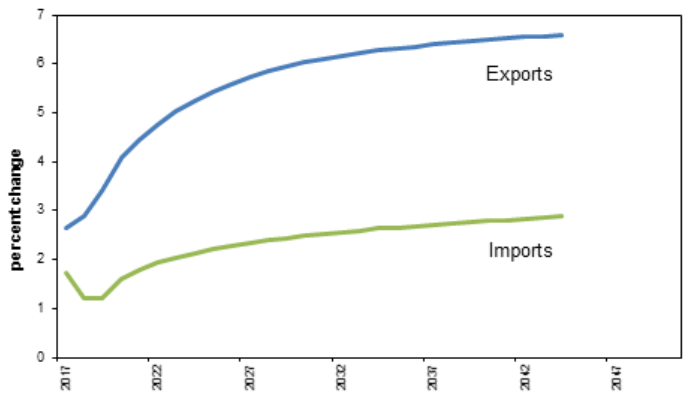

Exports and imports

Figure 10. Changes in government revenue and trade under corporate tax reform

\subsection{Sectoral Analysis}

Every sector grows faster with the reforms in the corporate income taxes than without reforms, at least by the end of the 25-year period covered by our simulation (Table 5). The machinery and instrument, and computer sectors grow faster than any other. These sectoral growth rates come mainly from the increased stock of capital across sectors, and the creation of more jobs across sectors.

The demand and supply for products in the markets increase because of the rise in the income of households and more investment by firms, leading to expansion across all sectors. The sectors that are more efficient attract more capital and create more jobs and grow faster. The underlying elasticities of substitution in consumption, production and trade also matter for the flexibility of markets and growth rates across these sectors.

Prices are lower relative to the benchmark because of the reduction in the cost production due to lower taxes of capital input.

Table 5. Percentage changes, relative to no-tax-change benchmark, by sector

\begin{tabular}{|c|c|c|c|c|c|c|c|c|}
\hline \multirow[b]{2}{*}{ Year } & \multicolumn{2}{|c|}{ Real output } & \multicolumn{2}{|c|}{ Capital stock } & \multicolumn{2}{|c|}{ Employment } & \multicolumn{2}{|c|}{ Relative prices } \\
\hline & 2017 & 2042 & 2022 & 2042 & 2017 & 2042 & 2017 & 2042 \\
\hline Period & 1 & 25 & 5 & 25 & 1 & 25 & 1 & 25 \\
\hline Agriculture, forestry and fishing & 2.9 & 5.7 & 4.0 & 8.6 & 6.3 & 4.6 & -1.0 & -4.2 \\
\hline Mining & 3.5 & 7.4 & 5.2 & 9.7 & 6.4 & 6.0 & -2.3 & -4.7 \\
\hline Construction & -2.5 & 1.2 & -1.6 & 5.3 & -2.3 & 1.1 & -1.5 & -2.8 \\
\hline Food and tobacco products & 0.8 & 4.1 & 2.4 & 7.2 & 7.1 & 4.8 & -1.5 & -4.5 \\
\hline Textiles and apparel & 2.3 & 5.1 & 0.0 & 9.6 & 7.3 & 6.6 & -1.2 & -3.6 \\
\hline Building materials & 1.8 & 4.1 & 2.0 & 8.0 & 4.4 & 3.9 & -1.3 & -3.4 \\
\hline Paper and publishing & 2.2 & 4.2 & 2.8 & 8.2 & 4.8 & 4.1 & -1.4 & -3.8 \\
\hline Chemicals, petroleum, rubber and plastics & 1.6 & 6.2 & 4.3 & 8.1 & 21.1 & 4.2 & -1.0 & -5.3 \\
\hline Electronics and electronic equipment & 0.4 & 2.6 & 0.6 & 3.8 & 2.3 & -0.7 & -1.1 & -3.8 \\
\hline Motor vehicles and other transportation & 3.4 & 5.0 & 4.7 & 9.8 & 7.5 & 6.2 & -1.4 & -4.1 \\
\hline Other manufacturing & 1.7 & 4.8 & 4.4 & 9.8 & 10.6 & 7.3 & -1.0 & -3.8 \\
\hline Transportation & 2.8 & 4.3 & 1.8 & 7.8 & 3.8 & 4.7 & -1.5 & -3.4 \\
\hline Communications & 3.7 & 4.9 & 3.7 & 8.9 & 7.4 & 6.6 & -2.3 & -4.4 \\
\hline Wholesale trade & 2.3 & 4.0 & 2.8 & 8.3 & 5.7 & 5.4 & -1.7 & -3.6 \\
\hline Retail trade & 2.5 & 4.4 & 1.9 & 7.6 & 6.6 & 6.8 & -1.5 & -4.1 \\
\hline Banking & 2.5 & 4.7 & 3.3 & 8.4 & 5.6 & 4.3 & -1.1 & -4.0 \\
\hline Real estate & 1.4 & 7.1 & 4.4 & 7.5 & 10.7 & 3.5 & 1.3 & -6.0 \\
\hline Personal and repair services & 0.8 & 2.5 & 0.1 & 6.7 & 1.0 & 4.1 & -1.8 & -2.0 \\
\hline Management and administration & 1.5 & 3.9 & 1.5 & 8.1 & 0.9 & 5.3 & -3.0 & -2.9 \\
\hline Health services & 0.8 & 0.7 & -3.8 & 1.0 & 1.1 & 1.1 & -1.0 & -2.2 \\
\hline Entertainment and hotel services & 1.1 & 2.4 & 0.4 & 6.0 & 1.8 & 2.3 & -1.3 & -3.0 \\
\hline Other services & 0.7 & 1.8 & -2.4 & 3.2 & 0.8 & 2.0 & -1.0 & -2.5 \\
\hline Computers & 2.7 & 5.8 & 6.0 & 11.1 & 10.9 & 8.7 & -0.6 & -3.6 \\
\hline Primary and fabricated metal & 1.8 & 4.7 & 1.8 & 8.1 & 1.7 & 5.0 & -2.6 & -3.7 \\
\hline Machinery and instruments & 5.4 & 7.4 & 5.6 & 11.0 & 12.7 & 8.6 & 0.3 & -3.7 \\
\hline Electricity - gas - sanitary & 3.5 & 6.4 & 3.6 & 8.3 & 5.9 & 4.4 & -2.1 & -5.1 \\
\hline Insurance & 1.2 & 5.5 & 3.5 & 8.7 & 5.4 & 4.5 & -1.0 & -5.3 \\
\hline
\end{tabular}

Source: Based on simulations using NCPA-DCGE model, of the effect of a 50 percent reduction in the corporate income tax rate. 


\section{Macro Impacts of Alternative Corporate Income Tax Rates}

Here we consider 100 and 25 percent reductions in the rate of corporate income tax across sectors, and replacing the existing corporate income tax rates with a 10 percent uniform rate across all sectors. Due to space limitations and the focus of this paper, only the macro effects of these alternative reform scenarios are reported here in Table 6.

Table 6. Summary of effects of alternative corporate income tax reforms

\begin{tabular}{|c|c|c|c|c|c|c|}
\hline Year & 2017 & 2022 & 2027 & 2032 & 2037 & 2042 \\
\hline Period & 1 & 5 & 10 & 15 & 20 & 25 \\
\hline \multicolumn{7}{|c|}{ Corporate income tax is abolished } \\
\hline Real GDP & 3.3 & 5.3 & 7.3 & 8.3 & 8.9 & 9.4 \\
\hline Investment & 15.7 & 16.5 & 17.2 & 17.5 & 17.9 & 18.4 \\
\hline Capital stock & 0.0 & 4.4 & 9.7 & 12.5 & 14.4 & 15.8 \\
\hline Employment & 6.1 & 6.9 & 7.1 & 7.1 & 7.2 & 7.3 \\
\hline Consumption & -0.6 & 2.3 & 5.1 & 6.3 & 6.9 & 7.1 \\
\hline \multicolumn{7}{|c|}{ Corporate income tax rate is reduced 25 percent } \\
\hline Real GDP & 0.8 & 1.2 & 1.6 & 1.8 & 2.0 & 2.1 \\
\hline Investment & 3.4 & 3.5 & 3.6 & 3.7 & 3.7 & 3.8 \\
\hline Capital stock & 0.0 & 0.9 & 2.0 & 2.6 & 3.0 & 3.3 \\
\hline Employment & 1.4 & 1.6 & 1.7 & 1.7 & 1.7 & 1.7 \\
\hline Consumption & 0.1 & 0.7 & 1.3 & 1.6 & 1.7 & 1.7 \\
\hline \multicolumn{7}{|c|}{ A 10 percent uniform corporate income tax is applied to all sectors } \\
\hline Real GDP & 0.6 & 0.7 & 0.9 & 0.9 & 0.9 & 0.9 \\
\hline Investment & 1.7 & 1.7 & 1.6 & 1.6 & 1.5 & 1.5 \\
\hline Capital stock & 0.0 & 0.5 & 1.0 & 1.3 & 1.4 & 1.5 \\
\hline Employment & 1.0 & 1.2 & 1.2 & 1.2 & 1.2 & 1.2 \\
\hline Consumption & 0.5 & 0.8 & 1.0 & 1.1 & 1.1 & 1.1 \\
\hline
\end{tabular}

Note. Numbers show percentage changes relative to benchmark of no tax change.

\section{Conclusion}

The reduction of the corporate tax rate changes output, investment, capital accumulation, and employment. This raises the level of consumption and lifetime utilities of households. Exports and imports expand. A DCGE model captures the details of prices, output, employment and investment by sector and income, as well as labor supply and utility for each decile of households. Both the growth and redistributional effects of reforms result in a slimmer public sector.

The model is also able to identify the complexity of the current tax system with detailed information on labor, and capital input taxes across sector, and sales, household income and social security taxes.

\section{Acknowledgments}

Research for this paper was conducted under a grant from the National Center for Policy Analysis, 14180 Dallas Parkway, Suite 350, Dallas, Texas 75254.

\section{References}

Angelini, J. P., \& Tuerck, D. G. (2015). The U.S. Corporate Income Tax: A Primer for U.S. Policymakers. The Beacon Hill Institute at Suffolk University. Retrieved from http://www.ncpa.org/pdfs/sp_The\%20U.S.\%20Corporate\%20Income\%20Tax.pdf

Arulampalam, W., Devereux, M. P., \& Maffini, G. (2012). The Direct Incidence of Corporate Income Tax on Wages. European Economic Review, 56(6), 1038-1054. https://doi.org/10.1016/j.euroecorev.2012.03.003

Bhattarai, K., Haughton, J., \& Tuerck, D. G. (2015a). Fiscal Policy, Growth and Income Distribution in the UK. Applied Economics and Finance, 2(3), 20-36. https://doi.org/10.11114/aef.v2i3.830

Bhattarai, K., Haughton, J., \& Tuerck, D. G. (2015b). The Economic Effects of the Fair Tax: Analysis of Results of a Dynamic CGE Model of the US Economy. International Economics and Economic Policy, 13(3), 451-466. https://doi.org/10.1007/s10368-016-0352-4 
Hall, R. E., \& Rabushka, A. (1985). The Flat Tax. Stanford CA: Hoover Press.

Leibrecht, M., \& Hochgatterer, C. (2012). Tax Competition as a Cause of Falling Corporate Income Tax Rates: A Survey of Empirical Literature. Journal of Economic Surveys, 26(4), 616-48. https://doi.org/10.1111/j.1467-6419.2010.00656.x

Mirrlees, J. S., Adam, T., Besley, R., Blundell, S., Bond, R., Chote, M., Gammie, P. J., Myles, G., \& Poterba, J. (2010). Dimensions of Tax Design: The Mirrlees Review. Oxford: Oxford University Press.

Overesch, M., \& Rincke, J. (2011). What Drives Corporate Tax Rates Down? A Reassessment of Globalization, Tax Competition, and Dynamic Adjustment to Shocks. The Scandinavian Journal of Economics, 113, 579-602. https://doi.org/10.1111/j.1467-9442.2011.01650.x

U.S. Council of Economic Advisers. (2015). Economic Report of the President. U.S. Government Printing Office, Washington DC.

Zellner, A., \& Ngoie, J. K. (2015). Evaluation of the Effects of Reduced Personal and Corporate Tax Rates on the Growth Rates of the U.S. Economy. Econometric Reviews, 34(1-5), 56-81. https://doi.org/10.1080/07474938.2014.944468

\section{Notes}

Note 1. General Algebraic Modeling Systems. http://www.gams.com/ and Mathematical Programming System for General Equilibrium Analysis. http://www.gams.com/solvers/mpsge/.

Note 2. CES aggregation, where the elasticity of substitution can take different values than 1 , is also considered in the model simulations.

Note 3. MPSGE was written by Thomas Rutherford for further explanation see his paper, "Applied General Equilibrium Modeling with MPSGE as a GAMS Subsystem: An Overview of the Modeling Framework and Syntax", University of Colorado, 1995; www.gams.com.

Note 4. The sectors for which we use an elasticity of substation in production are mining, building materials, paper and publishing, chemicals/petroleum/rubber/plastics, metals, machinery and instruments, electricity/gas/sanitation utilities, management and administrative services, business services, entertainment and hotel services, health services, and other services.

\section{Copyrights}

Copyright for this article is retained by the author(s), with first publication rights granted to the journal.

This is an open-access article distributed under the terms and conditions of the Creative Commons Attribution license (http://creativecommons.org/licenses/by/4.0/). 